\title{
Scribble promotes alveologenesis in the pregnant mammary gland for milk production
}

\author{
Shizu Aikawa ${ }^{1,2}$, Jia Yuan¹,2, Amanda Dewar,2, Xiaofei Sun ${ }^{1,2}$ and Sudhansu K Dey 1,2 \\ ${ }^{1}$ Division of Reproductive Sciences, Cincinnati Children's Hospital Medical Center, Cincinnati, Ohio, USA and \\ ${ }^{2}$ College of Medicine, University of Cincinnati, Cincinnati, Ohio, USA
}

Correspondence should be addressed to S K Dey; Email: sk.dey@cchmc.org

\begin{abstract}
Mammary glands are comprised of ducts and terminal lobules that form tree-like structures. Luminal epithelial cells in these lobules undergo differentiation into alveolar cells in pregnancy to support milk production. This study reveals that Scribble (SCRIB), a scaffold protein expressed in progesterone receptor (PGR)-positive cells, plays a critical role in mammary gland alveologenesis in mice. We conditionally deleted Scrib using a Pgr-Cre driver. PGR is heterogeneously expressed throughout the luminal epithelium. Scrib loss in mammary glands by Pgr-Cre (Scrib ${ }^{f / f}$ ggr $^{C r e /+}$ ) shows inefficient alveologenesis and terminal end bud (TEB)-like morphology during pregnancy, resulting in poor milk production and subsequent death of pups after delivery. The differentiation of PGR-positive epithelial cells into Elf5-expressing alveolar cells is defective in $\mathrm{Scrib}^{f / f} \mathrm{Pgr}^{\mathrm{Cr} /+}$ mice. These changes are reflected in reduced activation of JAK2 and PAK1, resulting in downregulation of pSTAT5, a critical transcriptional factor for alveologenesis. These results provide evidence that SCRIB impacts PGR-positive cell lineage during alveologenesis, which impacts milk production and the health of offspring.

Reproduction (2020) 159 719-731
\end{abstract}

\section{Introduction}

Functional mammary glands contribute to the health of offspring by providing nutrients and immunoglobulins via milk production (Palmer et al. 2006). Lobules and ducts inside the mammary glands form tree-like structures, with lobules developing alveoli, blooming flower-like structures that support milk production in pregnancy (Palmer et al. 2006, Paine \& Lewis 2017). Branching ducts work as pipes to transport milk from alveoli to a nipple (Palmer et al. 2006). At puberty, terminal end buds (TEBs) with a spoon-like structure are observed at the tips of each duct and contribute to ductal elongation and branching (Sternlicht 2006, Brisken \& Ataca 2015). TEBs regress once they reach the end of fat pads, and further branching occurs in response to estrous cycles to form lobular structures (Sternlicht 2006). During every pregnancy cycle, mammary epithelia undergo extensive proliferation and differentiation to establish milk producing epithelia (alveologenesis) that undergo involution at the cessation of nursing of pups and associated with changes in expressions of female hormone receptors for progesterone $\left(\mathrm{P}_{4}\right)$, estrogen $\left(\mathrm{E}_{2}\right)$ and prolactin (Prl) (Saji et al. 2000, Ismail et al. 2002, Palmer et al. 2006, Brisken \& Ataca 2015). Mammary glands are primarily comprised of luminal epithelial cells, basal epithelial (myoepithelial) cells and stromal fat cells (Brisken \& Ataca 2015). Luminal epithelial cells are major players in mammary gland development and differentiation, further classified by expressions of hormone receptors or transcriptional factors (Brisken \& Ataca 2015). Differentiation and function of luminal epithelial cells are highly dependent on $\mathrm{P}_{4}, \mathrm{E}_{2}$ and $\mathrm{Prl}$ as well as expression patterns of their receptors throughout puberty to adult stages (Lydon et al. 1995, Saji et al. 2000, Grimm et al. 2002, Mallepell et al. 2006). The progesterone $\left(P_{4}\right)$ receptor (PGR) is one of the core molecules to determine cell type and is also critical to the regulation of mammary development and function (Brisken \& Ataca 2015). In mice, newly formed corpora lutea produce higher levels of $P_{4}$ from day 3 of pregnancy and onward; $P_{4}$ level drops upon parturition (Cha et al. 2012). PGR is non-uniformly expressed in luminal epithelia, with high expression in TEBs and ductal tips followed by decreased expression as pregnancy progresses (Hovey et al. 2001, Ismail et al. 2002). Reports using mouse genetic models have shown that PGR-expressing epithelial cells contribute to cell proliferation and alveologenesis (Beleut et al. 2010, Lee et al. 2013, Brisken \& Ataca 2015).

To explore functions of specific genes in mammary epithelial cells, MMTV-Cre and Wap-Cre are primarily used (Wagner et al. 1997). Since MMTV-Cre is induced not only in luminal but also in basal epithelial cells, it poses difficulties in investigating the function of target genes in certain epithelial lineages (Wagner et al. 1997). 
Wap-Cre is induced specifically in alveolar cells, but efficient gene recombination occurs when females experience lactation (Wagner et al. 1997). Previously, we and others established mouse lines with Cre drivers expressed in specific epithelial cells: Pgr-Cre and LtfCre (Soyal et al. 2005, Daikoku et al. 2014). Pgr-Cre is expressed in PGR-positive cells and highly induced particularly in TEBs and the lobular tips of each duct (Soyal et al. 2005), whereas Ltf-Cre is induced in ductal epithelia (Daikoku et al. 2014). These Cre drivers are useful to investigate functions of specific genes of interest in a cell lineage-specific manner.

Scribble (SCRIB) is a scaffold protein involved in a variety of cellular functions by binding to other proteins responsible for specific signaling pathways, including epithelial cell polarity (Bonello \& Peifer 2019). There are reports on the importance of SCRIB in mammary glands (Zhan et al. 2008, Godde et al. 2014, Baker et al. 2016). In MCF10A, a mammary gland cell line with no PGR or estrogen receptor expression, Scrib knockdown suppresses myc-induced apoptosis, and transplantations of those cells resulted in tumorigenesis (Zhan et al. 2008). Mammary glands with Scrib knockout (KO) using MMTV-Cre also showed a tumorigenic phenotype due to compromised cell polarity and excessive expansion of ductal epithelia (Godde et al. 2014). Another study systemically knocked down Scrib in females before pregnancy; these mice showed decreased cell proliferation and alveologenesis because of reduced prolactin receptor (PRLR) expression on cell surfaces, while milk production was not affected (Baker et al. 2016). These studies with different phenotypes suggest that SCRIB has complex functions in mammary glands depending on cell types or physiological states, such as pregnancy.

Here, we show that SCRIB expressed in the PGRpositive cell lineage is critical for alveologenesis in pregnancy. Scrib $b^{f / f} \mathrm{Pgr}$ Cre/t females show poor milk production, resulting in the death of their offspring promptly after delivery. This defect is not observed in Scrib ${ }_{\mathrm{f} / \mathrm{LLtf}} \mathrm{Cr} / \mathrm{t}$ females. The phenotype in $\mathrm{Scrib}{ }^{\mathrm{f} / \mathrm{P}} \mathrm{Pg} \mathrm{Cre}^{\mathrm{Cr} / \mathrm{f}}$ females is not due to dysregulated cell polarity or abnormal cell death during early pregnancy, as previously reported in Scrib deletion in whole mammary glands. Scrib deletion in PGR-positive cell lineages results in the failure of luminal cells to differentiate into mature alveolar cells, depicted by reduced levels of Elf5 expression and a large accumulation of PGR-positive cells in lobular epithelia. In addition, pJAK2, pPAK1 and pSTAT5, which are indispensable factors for alveologenesis, are reduced in $\mathrm{Scrib}^{\mathrm{f} / \mathrm{Pg}} \mathrm{Pr}^{\mathrm{Cre} /+}$ tissues. Tridimensional (3D) imaging of mammary glands on days 4 and 12 of pregnancy shows that Scrib ${ }^{f / f} \mathrm{Pgr} r^{\mathrm{Cre} /+}$ tissues have TEB-like structures with higher levels of cell proliferation, suggesting abnormal differentiation of PGR-positive cell lineages. Our model using PGR-positive cell-specific gene deletion illuminates new insights into context-dependent SCRIB functions.

\section{Materials and methods}

\section{Mice}

$\mathrm{Pgr}^{\mathrm{Cre} /+}, \mathrm{Ltf}_{\mathrm{Cre} /+}$ and Scrib ${ }^{\mathrm{f} / \mathrm{f}}$ mouse lines were generated as previously described (Soyal et al. 2005, Hartleben et al. 2012, Daikoku et al. 2014). Conditional knockout mice of Scribble were generated by mating floxed females with either $\mathrm{Pgr} \mathrm{Cre}^{\mathrm{r}+}$ or $\mathrm{Ltf}^{\mathrm{Cr} /+}$ males. To confirm induction of $\mathrm{Ltf}$ Cre, Rosa26 ${ }^{\text {TdTomato }} \mathrm{Ltf}^{\mathrm{Cre} /+}$ females were generated by mating Rosa26 $6^{\text {TdTomato }}$ females (Jackson Lab) with Ltf Cre/+ $^{\text {males. }}$ All mice used in this study were housed under a constant 12-h/12-h light/dark cycle in the Cincinnati Children's Animal Care Facility according to $\mathrm{NIH}$ and institutional guidelines for the use of laboratory animals. All protocols were approved by the Cincinnati Children's Animal Care and Use Committee. Mice were provided ad libitum with autoclaved Laboratory Rodent Diet 5010 (Purina) and UV light-sterilized reverse osmosis/deionized constant-circulation water ad libitum.

\section{Preparation of pregnant females and collection of mammary glands}

Three adult females were randomly chosen and housed with a WT fertile male overnight in separate cages; the morning of finding the presence of a vaginal plug was considered successful mating (day 1 of pregnancy). Plug-positive females were then housed separately from males. The morning of finding delivered pups was defined as lactation day 1. Litter size and number of live/dead pups were counted until lactation day 2. To confirm pregnancy, plug-positive females were examined as follows: In plug-positive day 4 mice, one uterine horn was flushed with saline to confirm the presence of blastocysts. On day 5 of pregnancy, mice were intravenously injected with a blue dye solution ( $1 \%$ Chicago Blue in Saline, $100 \mu \mathrm{L} /$ mouse) 4 min before killing to confirm embryo implantation (Psychoyos 1973). On day 12 of pregnancy, the implantation sites are blatant. The fourth mammary glands which are located in the distal to the sternum were collected from each female as previously described (Plante et al. 2011).

\section{Carmine alum staining of whole mount mammary gland}

Carmine alum staining was performed as previously described (Plante et al. 2011). Briefly, the fourth mammary glands were attached to glass slides and fixed in Carnoy's fixative. Tissues were stained in Carmine Alum solution overnight $(\mathrm{O} / \mathrm{N})$ and dehydrated in ethanol and xylene. Pictures were taken using Nikon Eclipse 90i upright microscope.

\section{Immunofluorescence (IF)}

IF was performed as previously described (Yuan et al. 2018). IF using frozen sections $(12 \mu \mathrm{m})$ was performed using the following antibodies: Scribble (1:500, sc-28737, Santa Cruz), PGR (1:300, 8757; Cell Signaling technology), E-Cadherin (1:300, 3195s, Cell Signaling Technology), CK8 (1:1000, TROMA-1, Hybridoma Bank), Ki67 (1:300, RM-9106-S, Thermo Fisher Scientific), Cleaved Caspase-3 (1:300, 9661s, Cell Signaling technology), 
ZO-1 (1:300, 14-9776-82 Thermo Fisher Scientific), Radixin (1:300, sc-6408, Santa Cruz), pPAK1(Ser144)/pPAK2(Ser141) (1:300, 2606s, Cell Signaling Technology). For signal detection, secondary antibodies conjugated with Cy-2, Cy-5, Alexa 488, Alexa 594 or Alexa 647(1:300, Jackson Immuno Research) were used. Nuclear staining was performed using Hoechst 33342 (5 $\mathrm{\mu g} / \mathrm{mL}, \mathrm{H} 1399$, Thermo Fisher Scientific). Tissue sections from control and experimental groups were processed on the same slide. Pictures were taken using Nikon Eclipse TE2000-E. Numbers of Ki67-positive cells and nuclei were quantified using Image J (NIH).

\section{Immunohistochemistry (IHC)}

IHC using paraffin sections $(6 \mu \mathrm{m})$ was performed with the following antibodies: $\beta$-casein (1:300, sc-166530, Santa Cruz), pJAK2 (1:300, sc-294, Santa Cruz) and pSTAT5 (1:300, 9314s, Cell Signaling Technology). Signals were detected with DAB (Sigma) by following the manufacturer's protocol and counterstained with either hematoxylin (for $\beta$-casein and pJAK2) or eosin (pSTAT5). Pictures were taken using Nikon Eclipse E800.

\section{In situ hybridization}

Frozen sections from mice with each genotype were processed on the same slide. In situ hybridization with ${ }^{35}$ S-labeled cRNA probes was performed as described (Brisken et al. 2002) using probes for Prlr (Brisken et al. 2002) and Tnfsf11. Signals were visualized under a Nikon Eclipse E800 with dark-field. Fluorescence in situ hybridization was adopted based on previously established DIG in situ hybridization (Cha et al. 2014). In brief, following proteinase $\mathrm{K}(5 \mathrm{mg} / \mathrm{mL})$ digestion and acetylation, slides were hybridized at $55^{\circ} \mathrm{C}$ with the DIGlabeled Elf5 probe. Anti-Dig-peroxidase was applied onto hybridized slides following washing and peroxide quenching. Color was developed by TSA (Tyramide signal amplification) Fluorescein according to the manufacturer's instructions (PerkinElmer). Signals were visualized under a Nikon A1 Confocal Microscope. Following primers were used for the probes: 5'-GCATCGCTCTGTTCCTG-3' and 5'-TTTTCGTGC TCCСТССТTTC-3' for Rankl; 5'-AGCCAGTGTTATGGG TGCTG-3' and 5'-GGGGAAGTTAGGGTTCAGGG-3' for Elf5.

\section{Tridimensional visualization of mammary glands}

Whole mount staining, tissue clearing and 3D visualization of mammary glands were performed as previously described (Yuan et al. 2018) with some modification in the procedure of fixation. The fourth mammary glands were attached to glass slides and fixed in acetone at $-20^{\circ} \mathrm{C}, \mathrm{O} / \mathrm{N}$. Anti-CK8 antibody (1:300, TROMA-1, Hybridoma Bank), anti-PGR antibody (1:300, 8757; Cell Signaling technology), anti-Ki67 antibody (1:300, RM-9106-S, Thermo Scientific) and anti-Scrib antibody (1:300, sc-28737, Santa Cruz) were used as primary antibodies. Anti-rabbit antibody conjugated with Alexa 594 (1:300, Jackson ImmunoResearch) and anti-rat antibody conjugated with Cy2 (1:300, Jackson ImmunoResearch) were used as secondary antibodies. Dehydration in methanol was followed by tissue clearing by BABB (Benzyl alcohol: Benzyl benzoate (1:2); each reagent from Sigma-Aldrich) for $1 \mathrm{~h}$ at room temperature. The samples were then stored in the dark until 3D imaging acquisition. 3D images were acquired by a Nikon multiphoton upright confocal microscope (Nikon A1R) using LWD 10X objective with $3 \mu \mathrm{m}$ Z-stack.

\section{Statistical analysis}

Data are displayed as mean \pm S.E.M. The data were analyzed by one-way ANOVA followed by Bonferroni post hoc test. $P<0.05$ was considered statistically significant.

\section{Results}

\section{Scrib deletion in PGR-expressing cells results in poor milk production}

To examine the role of Scrib across cell lineages, we generated $\mathrm{Scrib}^{\mathrm{f} / \mathrm{P}} \mathrm{Pgr} \mathrm{Cre} /+$ and $\mathrm{SCrib}^{f / f} \mathrm{Ltf}$ Cre/+ females by mating mice harboring a specific Cre-driver with floxed Scrib mice (Hartleben et al. 2012). We found that almost $30 \%$ of pups from $\mathrm{Scrib}^{\mathrm{f} / \mathrm{Pg}} \mathrm{Pr} \mathrm{Cre} /+$ dams die within 2 days of delivery (Fig. 1A). The major cause of death appears to be malnourishment, as the pups from Scrib ${ }^{f / f} \mathrm{Pgr} C \mathrm{Cre} /+$ dams have poor milk accumulation in their stomachs (Fig. 1B). These Cre drivers are expressed in mammary glands (Soyal et al. 2005, Daikoku et al. 2014). We do observe the loss of Scrib in a group of mammary epithelial cells by IF in Scrib/f $P g r^{C r e /+}$ females (Fig. 2 and Supplementary Fig. 1A, B, see section on supplementary materials given at the end of this article).

We then asked whether milk production is compromised in Scrib ${ }^{f / f} \mathrm{Pgr}^{\mathrm{Cre} /+}$ females. Two markers for milk production, Oil-red-O (Fig. 3A) and $\beta$-casein staining (Fig. 3B), indicate poor milk secretions in these mutant mice. Normally, alveolar epithelial cells undergo extensive proliferation during lactogenesis in response to increasing demands of milk (Jahchan et al. 2012). In agreement with the reduced milk production, Scribdeletion in PGR-positive cells compromises proliferation depicted by Ki67 staining at the lactation stage (Fig. 3C and Supplementary Fig. 2).

Surprisingly, Scrib deletion using Ltf-Cre driver, which is also induced in mammary epithelial cells (Supplementary Fig. 1B) (Daikoku et al. 2014), does not result in obvious problems with the mothers in nursing pups. The different phenotypes between $\mathrm{Scrib}^{\mathrm{f} / \mathrm{f}} \mathrm{Pgr} \mathrm{Cre}^{\mathrm{C}+}$ and $S c r i b^{f / f} L t f^{C r e /+}$ mice are perhaps due to differential Pgr and Ltf expression: PGR is highly expressed in TEBs (Ismail et al. 2002), while Ltf is expressed in the ductal epithelia (Supplementary Fig. 1B) (Daikoku et al. 2014). In addition, Ltf expression levels are higher during involution rather than pregnancy stages (Neville \& Zhang 2000). There are reports showing that Ltf is poorly expressed in PGR- and PRLR-positive cells (Scheele et al. 2017, Casey et al. 2018) which are critical for alveologenesis (Brisken \& Ataca 2015). 
A

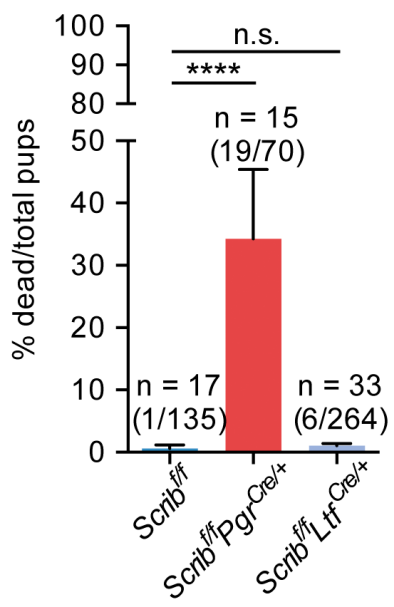

B

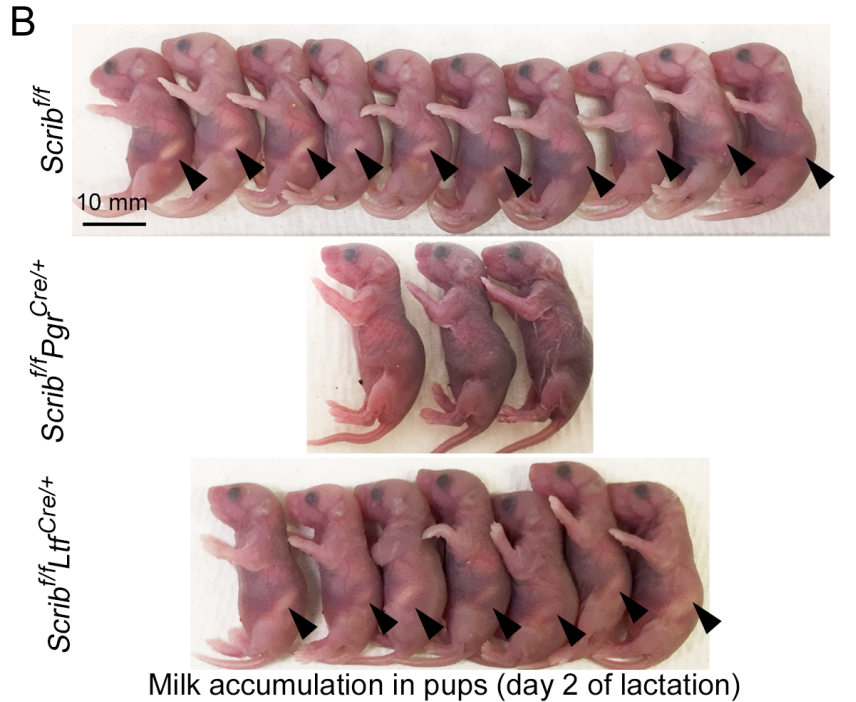

Figure $1 \mathrm{Scrib}^{\mathrm{f} / \mathrm{P}} \mathrm{Pg} r^{\mathrm{Cre} / \mathrm{t}}$ females fail to nourish new born pups. (A) The rate of dead pups among total pups from females with each genotype. $n$ : the number of total dams. The numbers of total dead pups/total delivered pups are noted within brackets above each bar. Data are means + S.E.M., $* * * * P<0.0001$ and n.s.: not significant by one-way ANOVA followed by Bonferroni post hoc test. (B) Representative pictures of pups from dams with each genotype on the next day of delivery (lactation day 2). Arrowheads indicate milk spots. Scale bar: $10 \mathrm{~mm}$.

Taken together, these observations suggest that Scrib is critical to the preparation of mammary glands for milk production, particularly related to PGR-expressing cells.

\section{Scrib deletion in PGR-expressing cells results in abnormal alveologenesis and associated with reduced Prl signaling}

We sought to explore the mechanism by which Scrib deletion in PGR-positive cells affects milk production during pregnancy. There have been reports that PGR signaling is important for mammary gland side branching, epithelial expansion and alveologenesis during development and pregnancy (Beleut et al. 2010, Lee et al. 2013, Brisken \& Ataca 2015). To examine when mammary development is affected by Scribdeletion in PGR-positive mammary epithelial cells, we performed whole-mount staining of mammary glands by Carmine Alum solution (Plante et al. 2011). Whole mount observations captured bigger terminal tips of each duct in $\mathrm{Scrib}^{\mathrm{f} / f} \mathrm{Pgr} \mathrm{Cre}^{++}$mammary glands (Fig. 4A, top). This morphology is further accentuated in the mid-stage of pregnancy (day 12); $\mathrm{Scrib}^{f / f} \mathrm{Pgr}^{\mathrm{Cre} /+}$ tissues show TEB-like structures, compared to fine branching

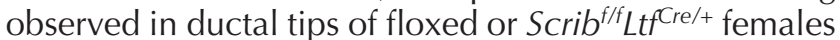
(Fig. 4A, middle). Eventually, Scrib ${ }^{\mathrm{f} / f} \mathrm{Pg}{ }^{\text {Cre/+ }}$ mammary glands develop flattened lobules in contrast to the blossoming alveoli of floxed and $\mathrm{SCrib}^{\mathrm{ff} / \mathrm{Ltf} \mathrm{Cre} /+}$ females (Fig. 4A, bottom). The enlarged TEB-like lobules in Scrib ${ }^{\mathrm{f} / \mathrm{Pgr}} \mathrm{Pre} /++$ mammary glands are more evident during the early stages of a second pregnancy (Fig. 4B).

PGR cooperatively works with Prolactin (PRL) signaling to establish milk-producing alveoli during pregnancy (Grimm et al. 2002, Obr et al. 2013, Sackmann-Sala et al. 2015, Bernard et al. 2019). With increasing PRL secretion during pregnancy, PRLR activates JAK2 (pJAK2), a downstream target, which in turn phosphorylates STAT5 (Shillingford et al. 2002). PAK1 is also a kinase that phosphorylates and facilitates nuclear translocation of STAT5 (Wang et al. 2003). There is evidence that SCRIB supports PAK1 activation by indirect binding to this protein (Nola et al. 2008, Zhan et al. 2008). Mice deficient in either of these mediators results in abnormal development and differentiation of mammary glands, indicating the importance of this signaling axis in this tissue (Brisken et al. 1999, Miyoshi et al. 2001, Shillingford et al. 2002, Wang et al. 2003). Phosphorylated nuclear STAT5 (pSTAT5) stimulates expression of paracrine factors, further expanding the signal cascades for alveologenesis (Hennighausen \& Robinson 2005). STAT5 can facilitate PGR-induced transcription of RANKL (Obr et al. 2013), another key factor for alveologenesis. It was shown that poor cell proliferation in PGR-deficient mammary glands is rescued by RANKL expression (Beleut et al. 2010), indicating the importance of the PRLR-pSTAT5-RANKL axis in the PGR-positive cell lineage.

These results prompted us to ask if Scrib-deletion in PGR-positive cells influences these signaling pathways. First, we examined the expression of Prlr. In situ hybridization shows it is comparable between each genotype (Fig. 5A). We then investigated whether downstream processes of PRLR are affected by Scrib deletion. Normally, pJAK2 is present in the cytosol of alveolar cells during mid-pregnancy (Fig. 5B). However, $\mathrm{Scrib}^{\mathrm{ff}} \mathrm{Pgr} \mathrm{Cre}^{\mathrm{C} /+}$ cells show lower levels of pJAK2 (Fig. 5B). In the same vein, pPAK1 is also reduced (Fig. 5C). These results are associated with reduced nuclear pSTAT5 levels in Scrib ${ }^{f / f} \mathrm{Pgr}^{\mathrm{Cr} /+}$ mammary epithelia compared to those of floxed or Scrib ${ }^{f / f} L_{f f}$ Cre/t+ females (Fig. 5D). 

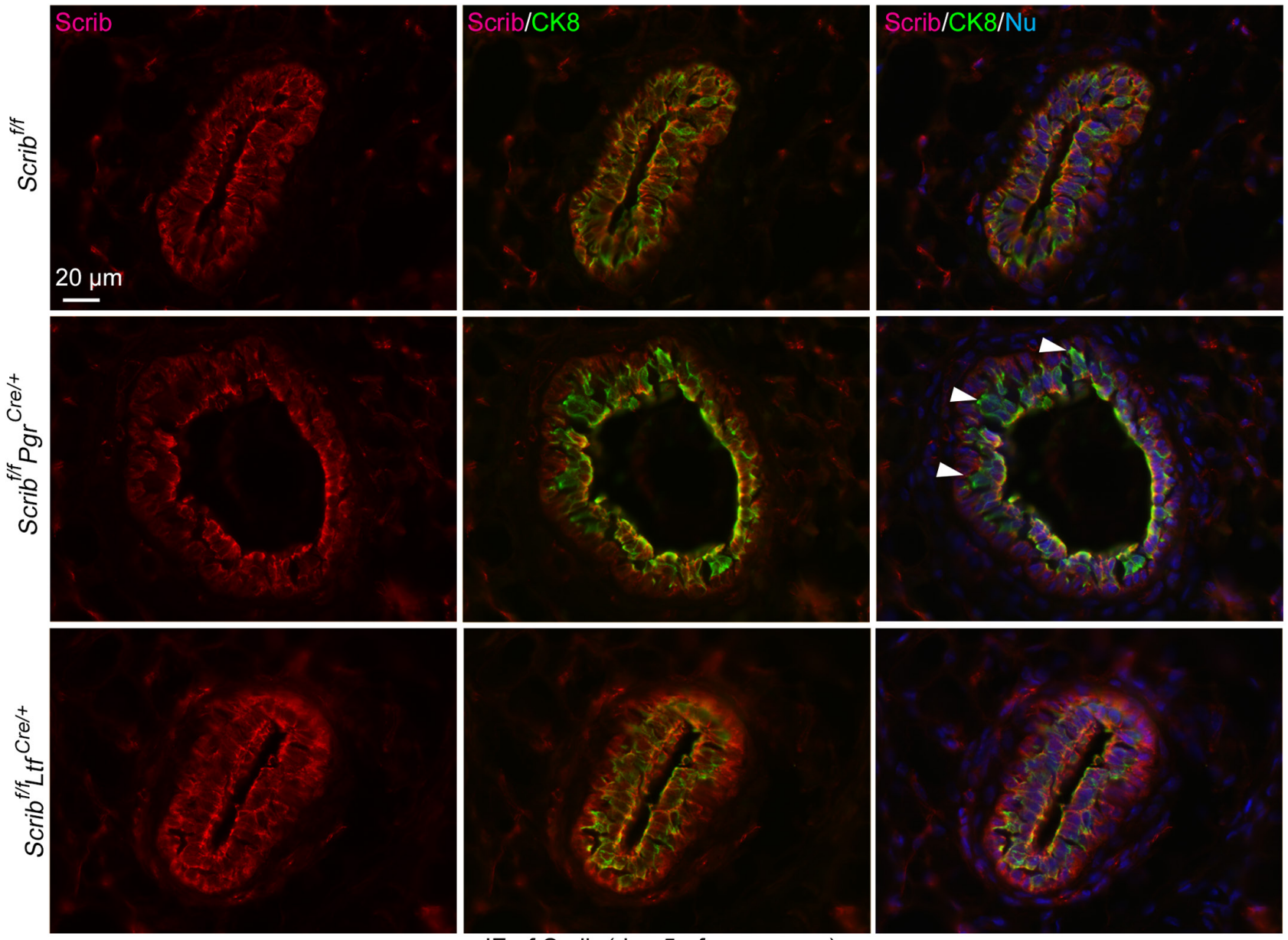

IF of Scrib (day 5 of pregnancy)

Figure 2 Deletion of Scrib in mammary glands by Pgr-Cre driver. IF of Scrib and CK8 in pregnancy day 5 mammary glands from females with each genotype. Arrowheads indicate the location of Scrib-deleted epithelial cells. Scale bar: $20 \mu \mathrm{m}$. Each image is a representative from at least three independent experiments.

These results led us to examine the levels of RANKL. Our in situ hybridization results show that Rankl is decreased in epithelia from Scrib/f/f $\mathrm{Pg}$ Cre/+ females (Fig. 5E). Taken together, these findings indicate the loss of SCRIB in PGR-positive cell lineages results in alveologenesis failure.

\section{Scrib-deletion in PGR-positive cell lineages results in $d y$ sregulated differentiation and expansion of PGR- positive cell lineages}

Our observations of poor alveologenesis in $S_{C r i b} b^{f / f} P g$ $r^{\mathrm{Cre} /+}$ mice raise the question as to how SCRIB in the PGR-positive cell lineage contributes to mammary cell differentiation into mature alveolar cells.

Abnormal epithelial cell polarity has been reported to yield abnormal functions of mammary glands (Akhtar \& Streuli 2006, Jahchan et al. 2012). SCRIB is a cell polarity component (Bonello \& Peifer 2019), and several studies featuring Scrib mutants show abnormal cell polarity in mammary epithelia and compromised alveologenesis (Zhan et al. 2008, Godde et al. 2014). However, Scrib ${ }^{f / f} \mathrm{Pgr}^{\mathrm{Cre} /+}$ mammary glands show normal apico-basal cell polarity as depicted by apical staining of ZO-1 (Fig. 6A). We also examined cell apoptosis, which was compromised by SCRIB loss in whole mammary epithelia (Zhan et al. 2008, Godde et al. 2014). In contrast to previous reports, apoptosis defined by the staining of cleaved-caspase- 3 also shows comparable levels in our mutant lines (Fig. 6B and Supplementary Fig. 3). These results indicate that SCRIB regulates PGRpositive cells specific to intracellular signaling but not cell polarity and cell death.

We performed 3D imaging of mammary glands after immunostaining of CK8 (a luminal epithelial cell marker) and PGR. PGR-expressing cells are highly populated in TEBs during puberty stages, but the number decreases in adults, especially during pregnancy (Ismail et al. 2002). However, Scrib ${ }^{f / f} \mathrm{Pgr}^{\mathrm{Cre} /+}$ mammary glands show higher levels of PGR-positive cells in lobules during midpregnancy (Fig. 7A). Previous studies have shown that $\mathrm{P}_{4}$-PGR signaling regulates mammary differentiation 


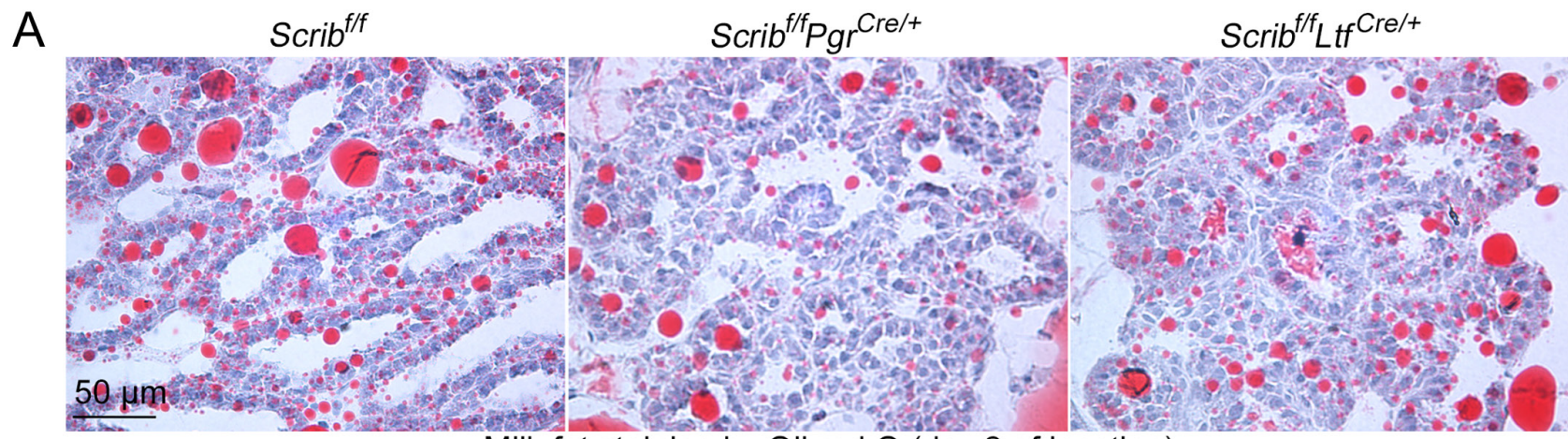

Milk fat staining by Oil red $\mathrm{O}$ (day 2 of lacation)

B

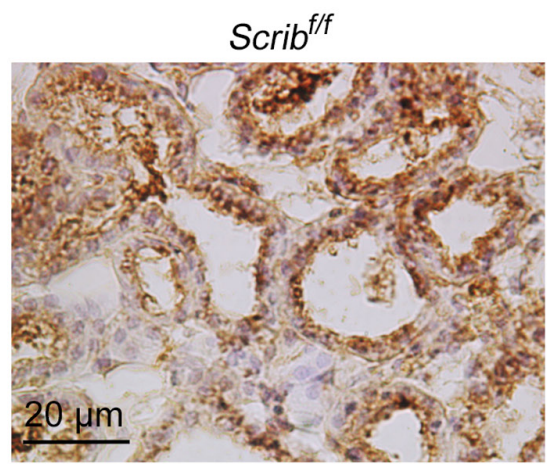

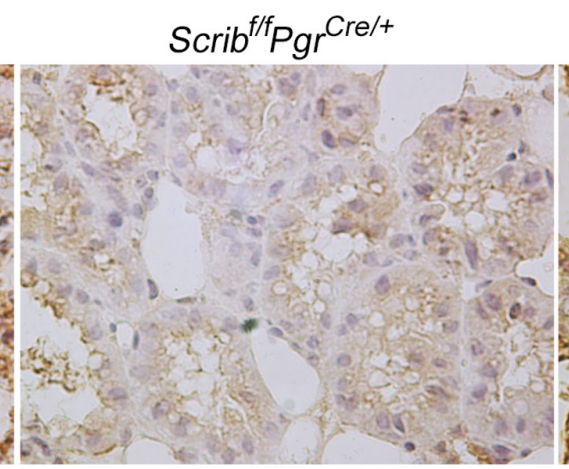

$\beta$-casein staining (day 2 of lactaion)

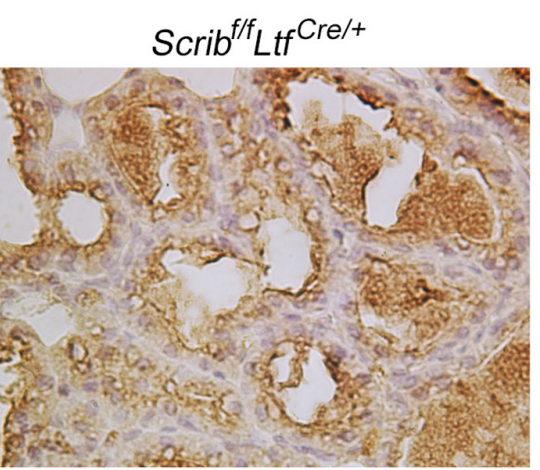

$\mathrm{Scrib}^{\mathrm{f} / \mathrm{Ltf}} \mathrm{Cre/+}$
C

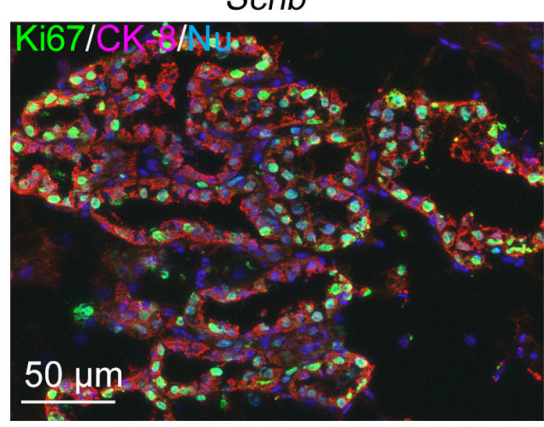

$\mathrm{Scrib}^{\mathrm{f} / \mathrm{P} \mathrm{Pgr}} \mathrm{Cre/+}$

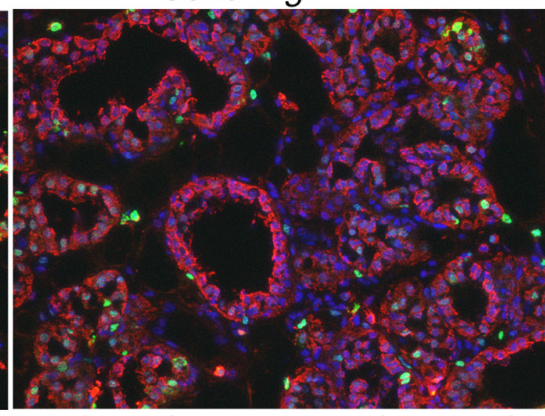

$\mathrm{Scrib}^{f / f} L \mathrm{tf}$ Cre/+

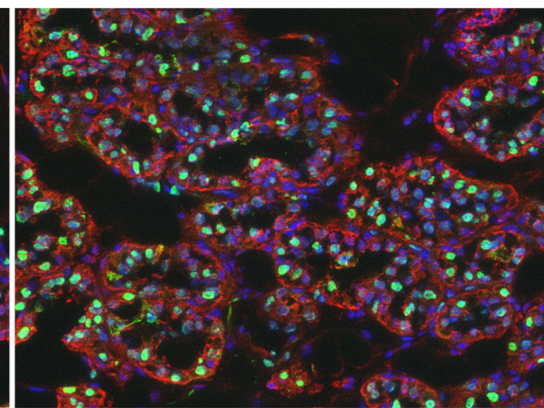

Staining of proliferating cells (day 2 of lactation)

Figure 3 Abnormal milk production in Scrib ${ }^{f / f} \mathrm{Pgr}^{\mathrm{Cre} /+}$ mammary glands. (A and B) Oil red O staining (A) and IHC of $\beta$-casein (B) show poor milk production in Scrib ${ }^{f / f} \mathrm{ggr}^{\mathrm{Cre} /+}$ mammary glands on lactation day 2. Scale bar: $50 \mu \mathrm{m}$ (A) and $20 \mu \mathrm{m}$ (B). (C) IF of Ki67 (cell proliferation marker) and CK8 (epithelial cell marker) indicates reduced proliferation of alveolar cells in Scrib ${ }^{f / f} \mathrm{Pgr}{ }^{\mathrm{Cre} /+}$ mammary glands on lactation day 2 . Scale bar: $50 \mu \mathrm{m}$. Each image is a representative from at least three independent experiments.

and proliferation via a transcriptional factor ELF5 (Oakes et al. 2008, Lee et al. 2013). ELF5 is highly induced in mature alveolar cells with a mutual exclusion with PGR (Lee et al. 2013) and ELF5 deletion in mammary glands results in differentiation failure of milk-producing cells (Oakes et al. 2008). $P_{4}$-PGR axis stimulates RANKL expression to drive the maturation of mammary epithelial cells into secretory cells by Elf5 induction (Lee et al. 2013). Our in situ hybridization shows that Elf5 is reduced in $\mathrm{Scrib}^{\mathrm{f} / \mathrm{Pgr}} \mathrm{Pre} /+$ mammary glands during mid-pregnancy (Fig. 7B). Considering the increased population of PGR-positive cells, this result indicates that cell differentiation is compromised during pregnancy.
In accord with these observations, the expression of Rankl is also reduced in Scrib $b^{f / f} \mathrm{PgCr}{ }^{\text {re/t }}$ mammary glands (Fig. 5E). We further traced back defects in the mutant alveoli. 3D Imaging during early pregnancy reveals that enlarged gland tips in $\mathrm{Scrib}^{\mathrm{f} / \mathrm{Pg}} \mathrm{Pr}^{\mathrm{Cre} /+}$ show relatively high expression of PGR similar to puberty stage TEBs (Fig. 7C) (Ismail et al. 2002). In addition, we found increased cell proliferation in TEB-like structures of Scri $b^{f / f} \mathrm{Pgr}^{\mathrm{Cre} / \mathrm{t}}$ tissues, in which PGR-positive cells are highly abundant (Fig. 7D). This finding contrasts with previous observations in the systemic knockdown of Scrib with poor mammary cell proliferation during early pregnancy (Baker et al. 2016), further supporting our notion that 


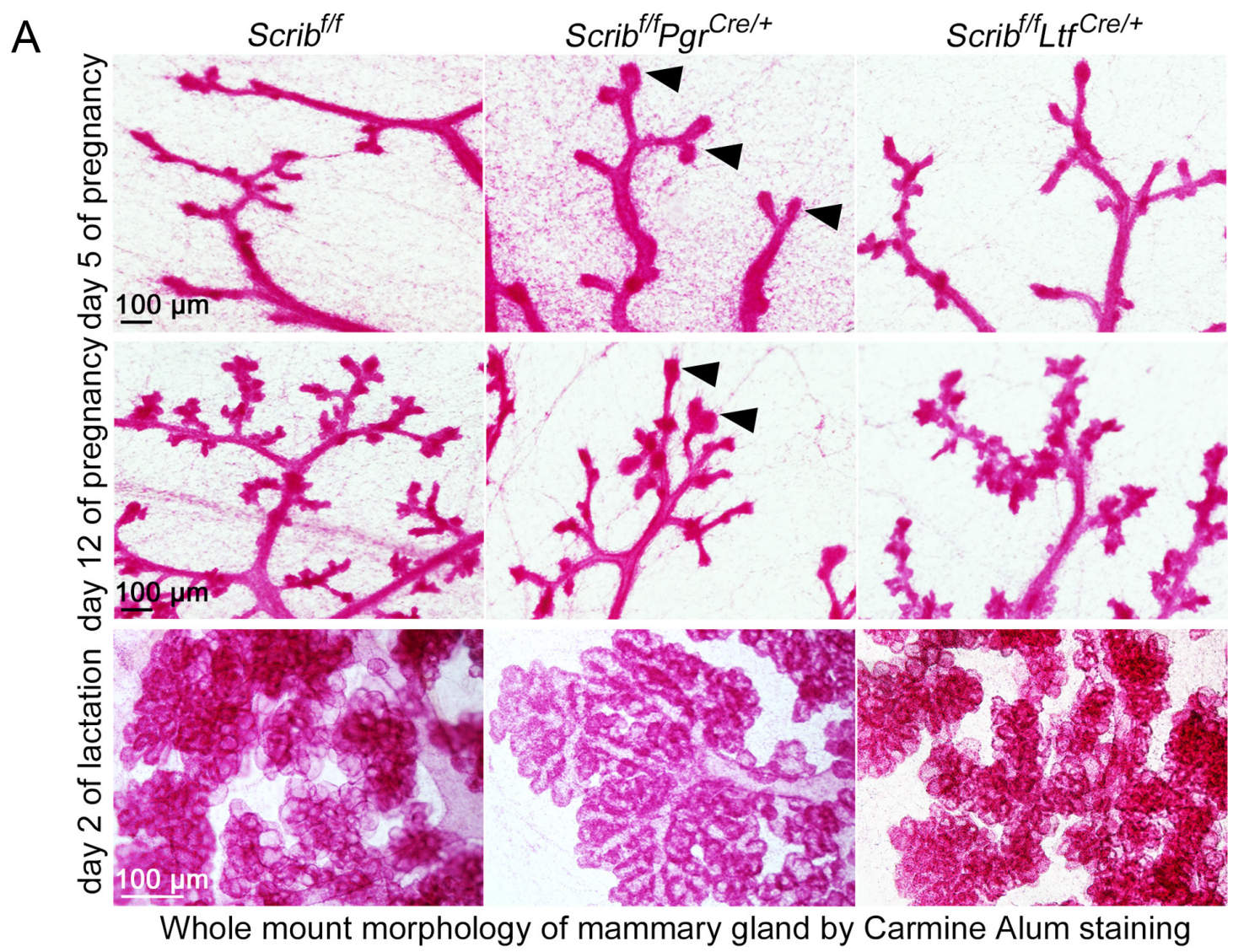

B

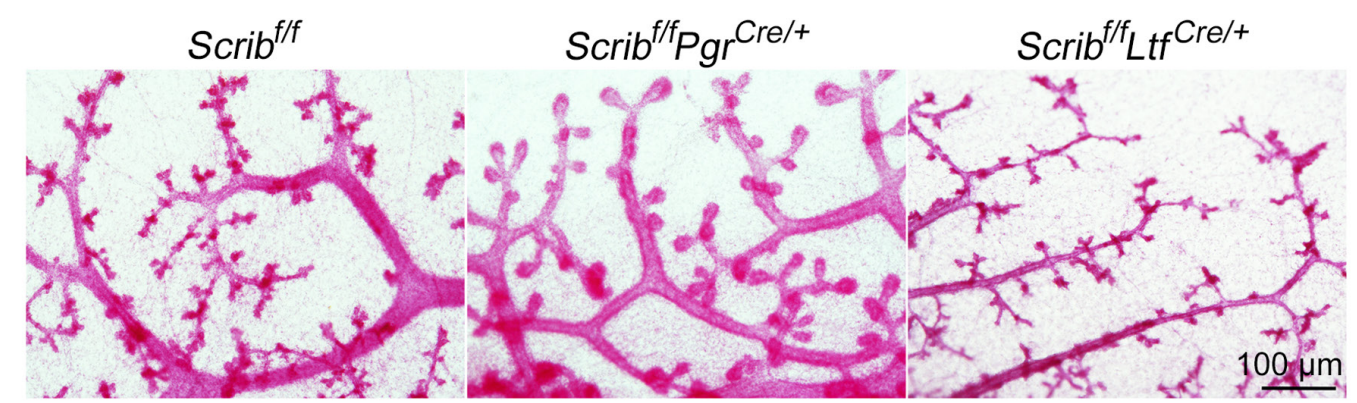

Whole mount morphology of mammary gland by Carmine Alum staining (day 5 of 2nd pregnancy)

Figure 4 Abnormal alveologenesis in Scrib/f/f $\mathrm{gr}^{\mathrm{Cre} / \mathrm{t}}$ females. (A) Carmine Alum staining of whole mount mammary glands was performed using tissues from each genotype on pregnancy day 5 (top), pregnancy day 12 (middle) and lactation day 2 (bottom). Scale bar: 100 m. (B) Carmine alum staining of whole mount mammary glands on day 5 of 2 nd pregnancy. Scale bar: $100 \mu \mathrm{m}$. Each image is a representative from at least three independent experiments.

SCRIB exerts a unique function in the PGR-positive cell lineage. In summary, our results indicate SCRIB in PGRpositive cells modulates cell differentiation into mature milk-producing cells via Elf5-induction.

\section{Discussion}

In this study, we illuminate the critical roles played by SCRIB in PGR-positive mammary epithelial cells for epithelial differentiation during pregnancy. Scrib deletion using a Pgr-Cre driver results in defective cell differentiation of milk-producing mature cells.

Previous studies in mice have illustrated the complexities of SCRIB function in mammary glands (Table 1): Scrib knockdown in hormone receptornegative mammary cells undergo tumorigenesis (Zhan et al. 2008). MMTV-Cre induced global deletion of Scrib in mammary epithelia resulted in ductal hyperplasia (Godde et al. 2014), while whole-body knockdown of Scribble in adult females showed poor alveologenesis 
A

$\mathrm{Scrib}^{\mathrm{f} / \mathrm{f}}$

$\mathrm{Scrib}^{\mathrm{fff}} \mathrm{Pgr} \mathrm{Cre}^{\mathrm{C}+}$
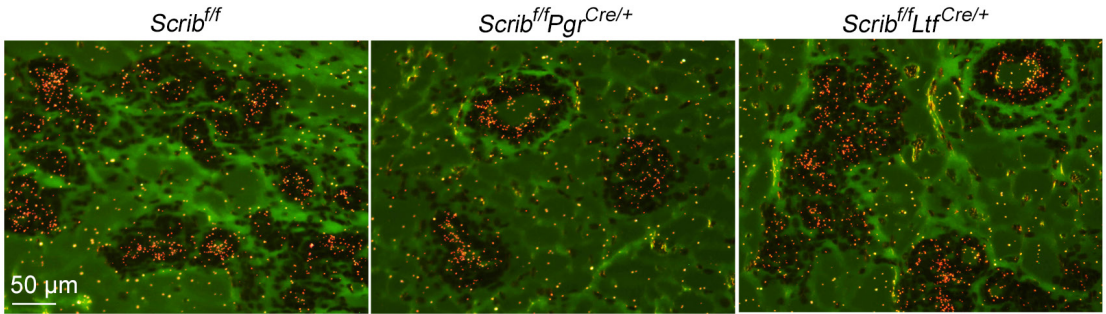

in situ hybridization of PrIr (day 12 of pregnancy)

B

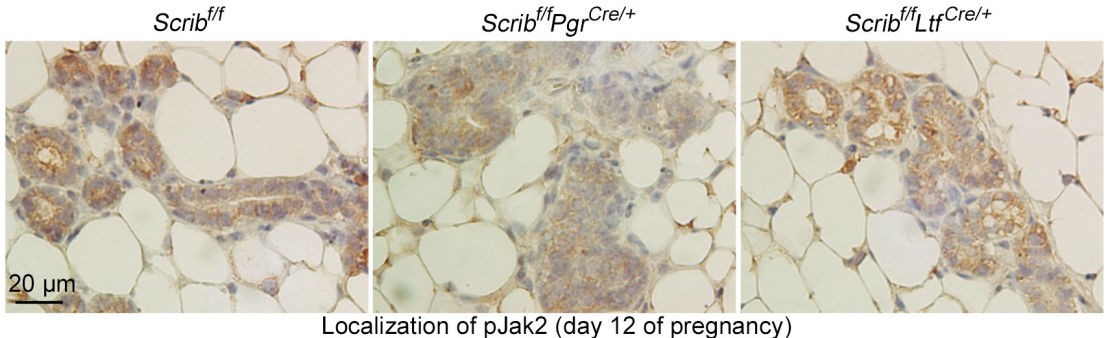

C

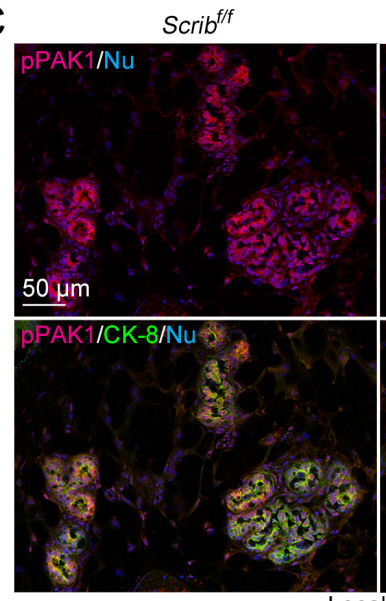

$\mathrm{Scrib}^{\mathrm{ff}} \mathrm{Pgr}_{\mathrm{Cr}} \mathrm{C}+$

$\mathrm{Scrib}^{\mathrm{f} / \mathrm{L} L \mathrm{tf}} \mathrm{Cre/+}$

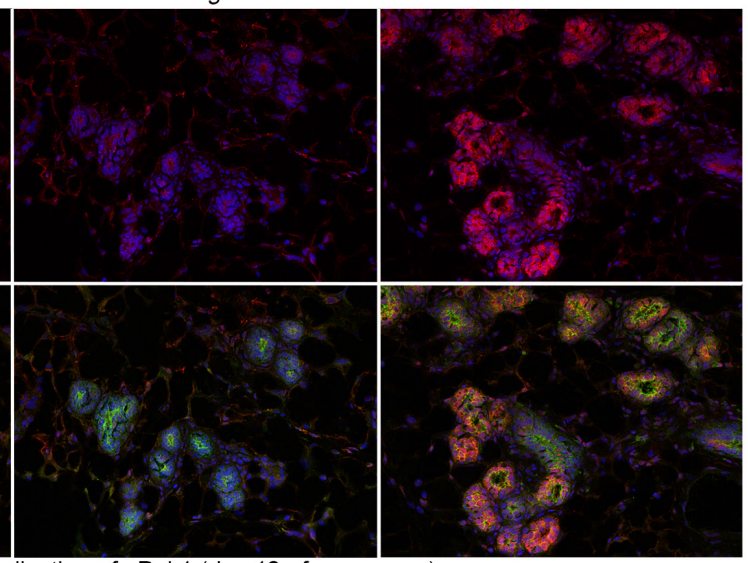

Localization of pPak1 (day 12 of pregnancy)

D

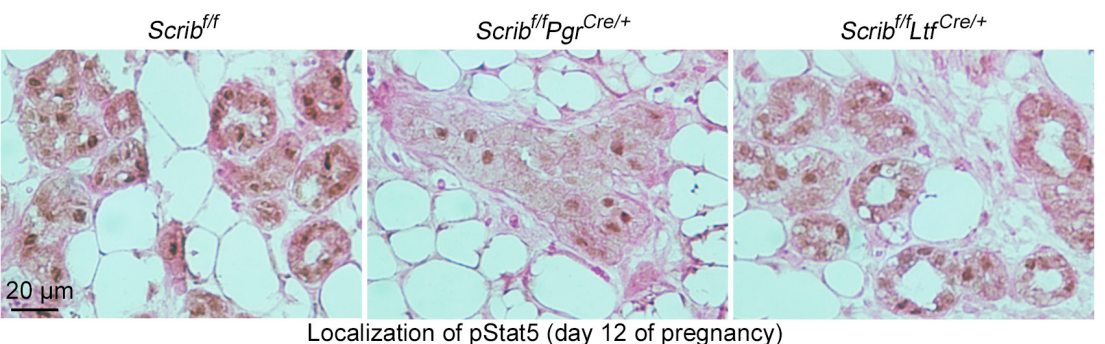

E

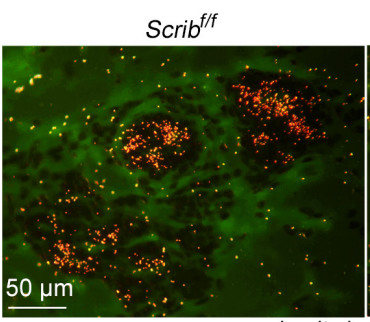

$\mathrm{Scrib}^{\mathrm{fff}} \mathrm{Pgr} \mathrm{Cre}^{\mathrm{C}}+$

$\mathrm{Scrib}^{\mathrm{f} / \mathrm{L} L \mathrm{Lf}} \mathrm{Cre} /+$
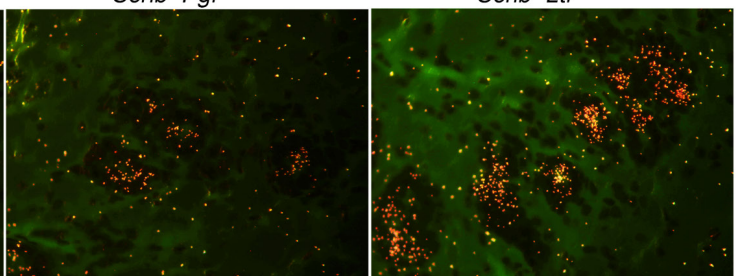

in situ hybridization of Rankl (day 12 of pregnancy)

Figure 5 Reduced JAK2-PAK1-STAT5 signaling in Scrib ${ }^{f / f} \mathrm{Pgr}^{\mathrm{Cre} /+}$ mammary glands. (A) In situ hybridization of Prlr (brownish yellow) in pregnancy day 12 mammary epithelia from females with each genotype. Scale bar: $50 \mu \mathrm{m}$. (B) IHC of pJAK2 with Hematoxylin counter staining in pregnancy day 12 mammary glands from females with each genotype. Scale bar: $20 \mu \mathrm{m}$. (C) IF of pPAK1/pPAK2 in pregnancy day 12 mammary glands from females with each genotype. Scale bar: $50 \mu \mathrm{m}$. (D) IHC of pSTAT5 with Eosin counter staining in pregnancy day 12 mammary glands from females with each genotype. Scale bar: $20 \mu \mathrm{m}$. (E) In situ hybridization of Rankl (brownish yellow) in pregnancy day 12 mammary glands from females with each genotype. Scale bar: $50 \mu \mathrm{m}$. Each image is a representative of at least three independent experiments. 


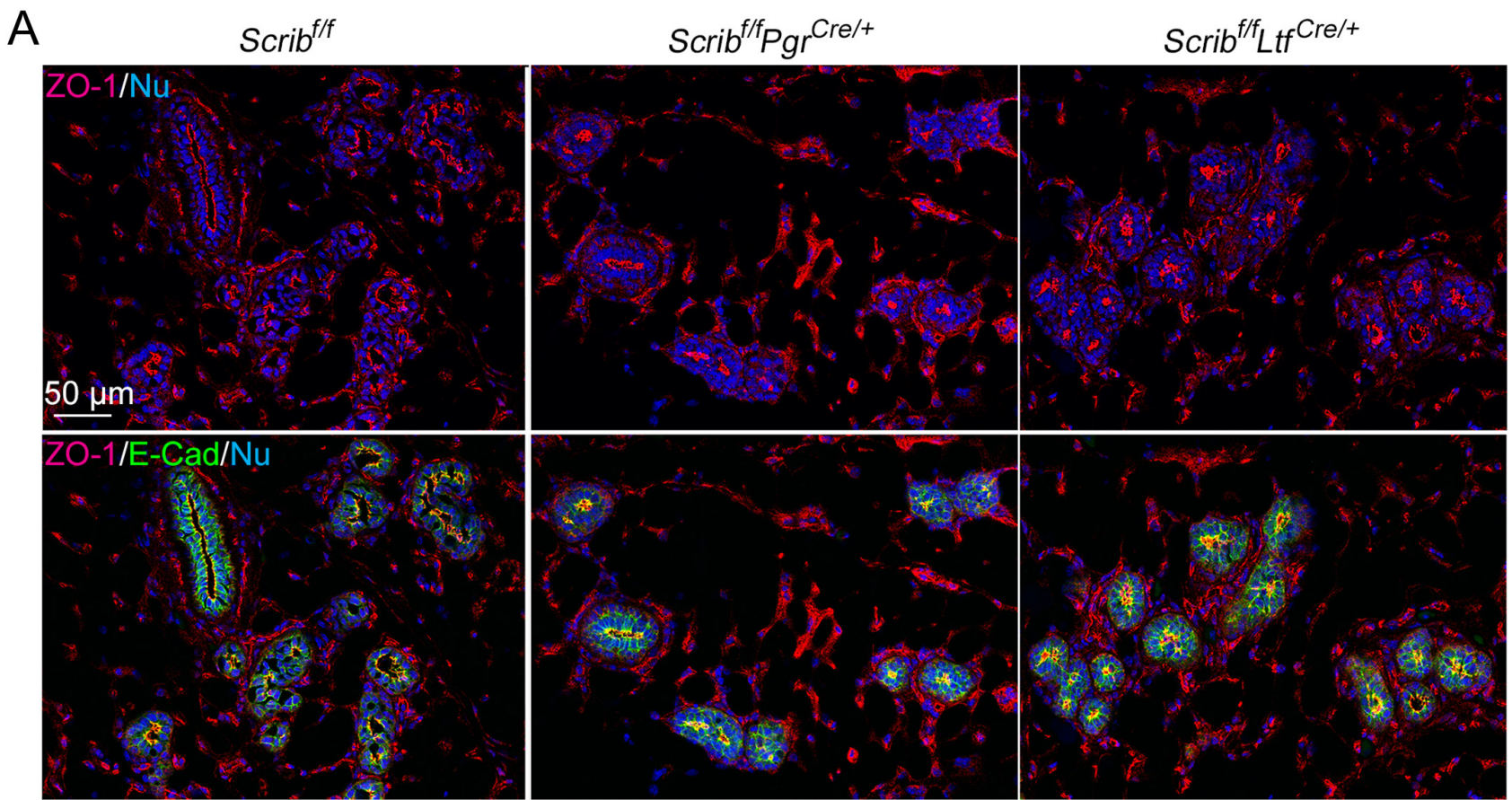

Staining of apical surface (day 12 of pregnancy)

B

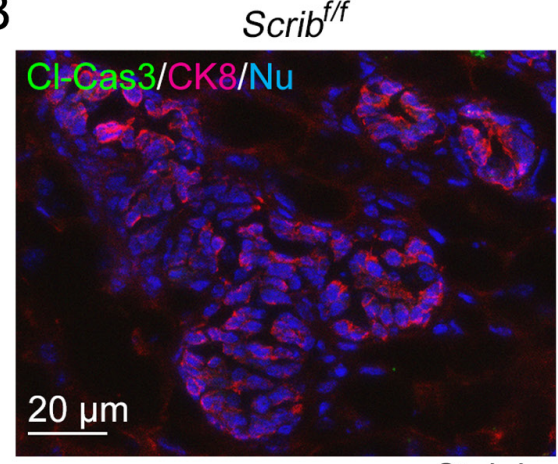

$\mathrm{Scrib}^{\mathrm{f} / \mathrm{P}} \mathrm{Pgr} \mathrm{Cre} /+$

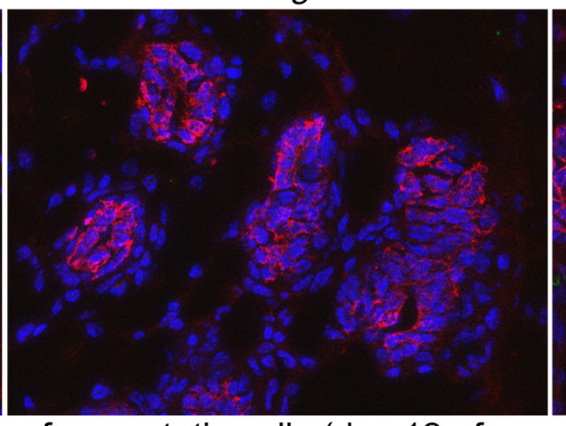

$\mathrm{Scrib}^{\mathrm{f} / \mathrm{L} L \mathrm{tf}} \mathrm{Cre/+}$

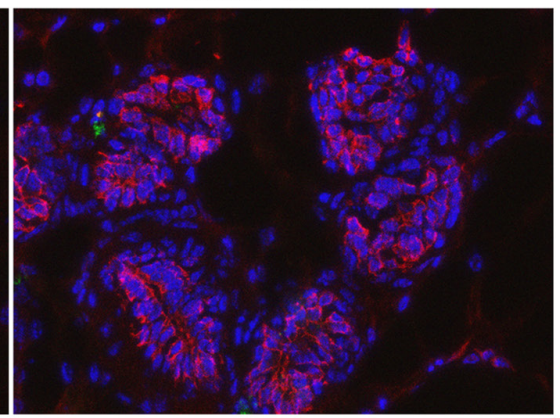

Staining of apooptotic cells (day 12 of pregnancy)

Figure 6 Comparable cell polarity and apoptosis in Scrib/ff $\mathrm{Pgr}$ Cre/+ mammary epithelia. (A) Cell polarity was depicted by IF of ZO-1 using pregnancy day 12 tissues. ZO-1 is localized on the apical surface of epithelia. Scale bar: $50 \mu \mathrm{m}$. (B) IF of cleaved caspase-3 (Cl-Cas3; apoptosis marker) and CK8 in pregnancy day 12 mammary gland tissues from each genotype. Scale bar: $20 \mu \mathrm{m}$. Each image is a representative from at least three independent experiments.

but normal milk production upon pregnancy (Baker et al. 2016). In contrast to these reports, our model using $\mathrm{SCrib}^{f / f} \mathrm{Pgr}{ }^{\mathrm{Cre} /+}$ females demonstrates the importance of SCRIB in the PGR-positive cell lineage for alveologenesis to prepare for milk production. Scrib ${ }^{f / f} \mathrm{Pgr}^{\mathrm{Cre} /+}$ mammary glands show abnormal alveolar formation depicted by enlarged and poorly bubbled lobules akin to TEBs in mammary glands at the time of puberty. This anomaly is accompanied by impaired PRLR signaling. While PRLR levels are comparable between each genotype, phosphorylated JAK2, PAK1 and STAT5 are reduced in this mutant line, resulting in reduced levels of RANKL, which is critical for PGR-induced mammary functions
(Beleut et al. 2010, Obr et al. 2013). Lobules in Scrib ${ }^{f / f} \mathrm{Pgr}$ Cre/t+ tissues contain increased numbers of PGRpositive cells with higher cell proliferation during early pregnancy. In contrast, Scrib ${ }^{f / f} \mathrm{Pgr}^{\mathrm{Cre} /+}$ lobules fail to proliferate in response to increasing demands for milk at the lactation stage. These anomalies in cell proliferation during pregnancy or lactation indicate compromised differentiation of luminal epithelial cells. Normally, PGR is highly expressed in TEBs and lobules, which are primary drivers for mammary epithelial expansion and differentiation (Paine \& Lewis 2017). The number of PGRpositive cells declines with progression of pregnancy and an increasing population of ELF5-positive cells that 

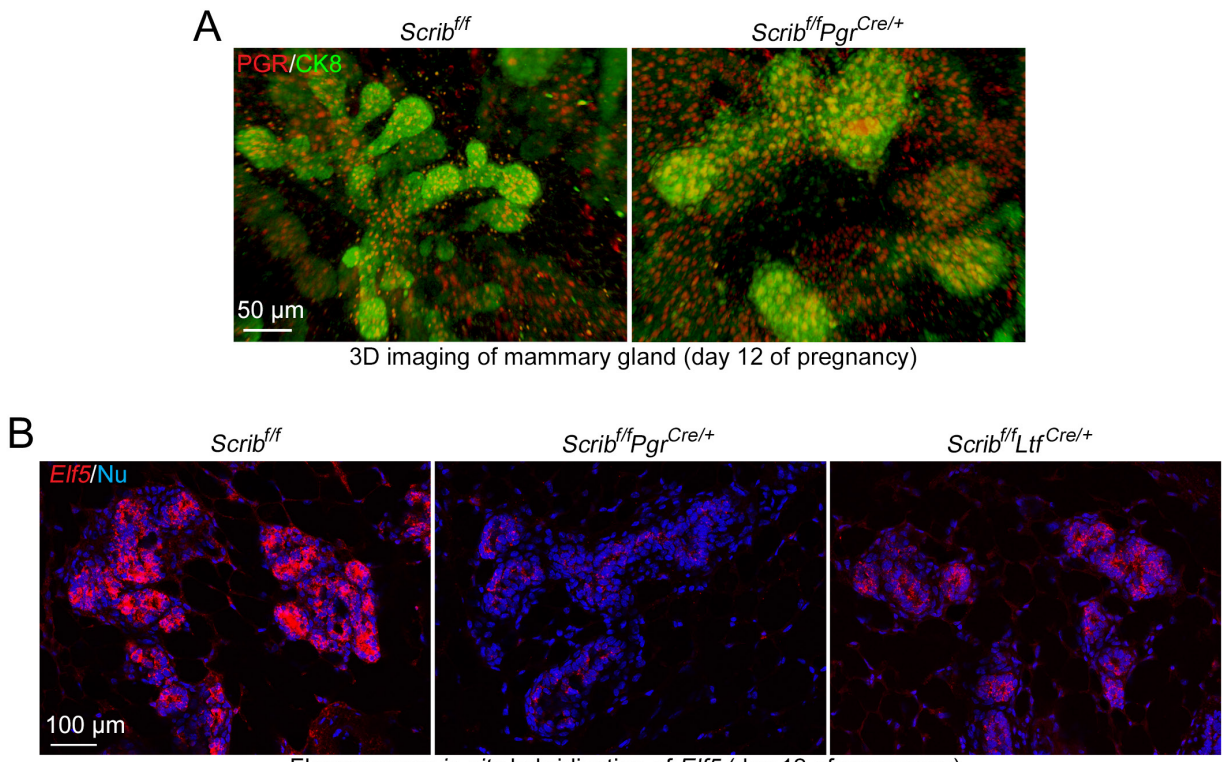

Fluorescence in situ hybridization of Elf5 (day 12 of pregnancy)

C
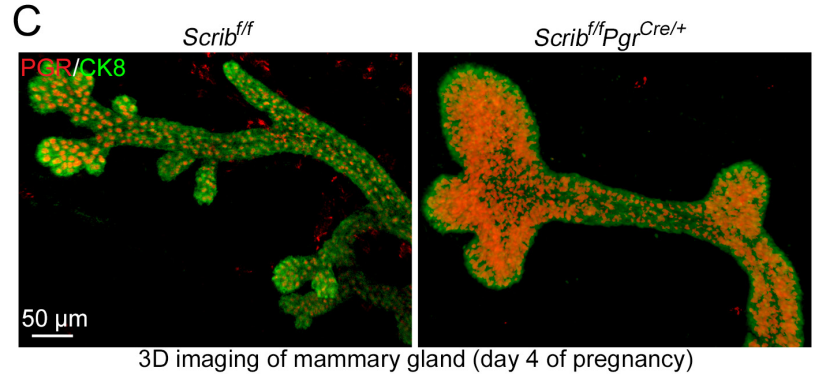

(1) pregnancy)
D
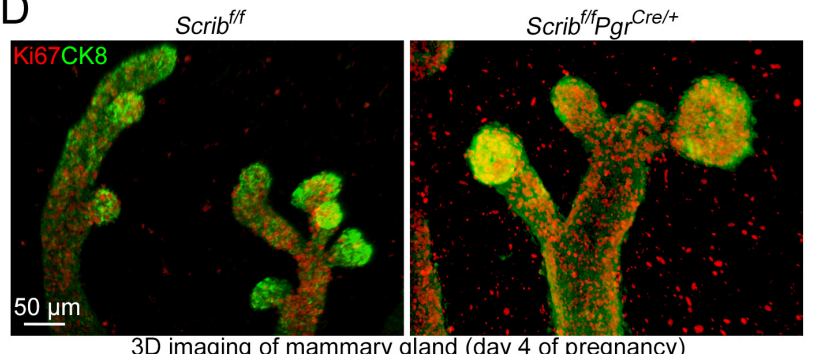

3D imaging of mammary gland (day 4 of pregnancy)

Figure $7 \mathrm{Scrib}{ }^{f / f} \mathrm{Pgr}^{\mathrm{Cre} /+}$ mammary glands fail to differentiate into mature alveolar cells. (A) Snapshots of tridimensional (3D) imaging of mammary glands from floxed and Scrib ${ }^{f / f} \mathrm{Pgr} r^{\text {Cre/+ }}$ females on pregnancy day 12. Tissues were stained using antibodies for CK8 (epithelial marker) and PGR. Scale bar: $50 \mu \mathrm{m}$. (B) Fluorescence in situ hybridization of Elf5 in pregnancy day 12 mammary glands from females with each genotype. Scale bar: $100 \mu \mathrm{m}$. (C) Snapshots of 3D imaging of mammary glands from floxed and Scrib ${ }^{f / f} \mathrm{Pgr} \mathrm{C}^{\mathrm{Cr} / \mathrm{+}}$ females on pregnancy day 4 . Tissues were stained using antibodies for CK8 (epithelial marker) and PR. Scale bar: $50 \mu \mathrm{m}$. (D) Snapshots of 3D imaging of mammary glands from floxed and Scrib ${ }^{f \prime}$ ${ }^{f} \mathrm{Pgr} r^{\mathrm{Cre} / \mathrm{+}}$ females on pregnancy day 4. Tissues were stained using antibodies for CK8 (epithelial marker) and Ki67. Scale bar: $50 \mu \mathrm{m}$. Spotty signals outside of luminal layer in A, C and D are non-specific stainings caused by blood cells. 3D images were acquired by a Nikon multiphoton upright confocal microscope (Nikon A1R) using LWD 10X objective with $3 \mu \mathrm{m}$ Z-stack. Each image is a representative from at least three independent experiments.

Table 1 Summary of mammary phenotypes in each Scrib-deleted model.

\begin{tabular}{|c|c|c|c|c|c|}
\hline Report & Cell/Cre lines & Phenotype & Cell polarity & Proliferation & Apoptosis \\
\hline $\begin{array}{l}\text { Zhan et al. } \\
2008\end{array}$ & $\begin{array}{l}\text { MCF10A (human, } \\
\text { PGR-negative basal } \\
\text { cells) }\end{array}$ & $\begin{array}{l}\text { Increased tumorigenesis } \\
\text { upon c-Myc } \\
\text { overexpression }\end{array}$ & $\begin{array}{l}\text { Compromised } \\
\text { apico-basal } \\
\text { polarity }\end{array}$ & Comparable & Decreased \\
\hline $\begin{array}{l}\text { Godde et al. } \\
2014\end{array}$ & $\begin{array}{l}\text { MMTV-Cre (Whole } \\
\text { mammary epithelia) }\end{array}$ & $\begin{array}{l}\text { Ductal hyperplasia } \\
\text { and increased } \\
\text { tumorigenesis }\end{array}$ & $\begin{array}{l}\text { Compromised } \\
\text { apico-basal } \\
\text { polarity }\end{array}$ & $\begin{array}{l}\text { Increased in ductal luminal } \\
\text { cells but not in TEBs at } \\
12 \text {-weeks old }\end{array}$ & $\begin{array}{l}\text { Decreased in newly- } \\
\text { formed ductal luminal } \\
\text { cells but not in TEBs at } \\
\text { 6-weeks old }\end{array}$ \\
\hline $\begin{array}{l}\text { Baker et al. } \\
2016\end{array}$ & $\begin{array}{l}\text { Cola1-Dox inducible } \\
\text { KD (Whole body) }\end{array}$ & $\begin{array}{l}\text { Poor alveologenesis but } \\
\text { normal milk production }\end{array}$ & Not affected & $\begin{array}{l}\text { Reduced during early } \\
\text { and mid-pregnancy }\end{array}$ & Not affected \\
\hline \multirow[t]{2}{*}{ This paper } & $\begin{array}{l}\text { Pgr-Cre (PGR-positive } \\
\text { cells) }\end{array}$ & $\begin{array}{l}\text { TEBs-like morphology } \\
\text { during pregnancy with } \\
\text { poor milk production }\end{array}$ & Not affected & $\begin{array}{l}\text { Increased populations of } \\
\text { PGR-positive cells in } \\
\text { TEBs-like lobules during } \\
\text { early pregnancy }\end{array}$ & Not affected \\
\hline & $\begin{array}{l}\text { Ltf-Cre (Ductal } \\
\text { epithelia) }\end{array}$ & $\begin{array}{l}\text { Normal mammary } \\
\text { morphology and } \\
\text { functions }\end{array}$ & Not affected & Not affected & Not affected \\
\hline
\end{tabular}


behave as mature secretory cells (Ismail et al. 2002, Lee et al. 2013). However, Scrib ${ }^{f / f} \mathrm{Pgr}{ }^{\mathrm{Cre} /+}$ mammary glands show poor expression of Elf5 during pregnancy. This observation is consistent with our notion that SCRIB in PGR-positive cells is critical to differentiation of mammary epithelial cells into mature alveolar cells. In contrast to the increased cell proliferation during early pregnancy, Scrib ${ }^{f / f} \mathrm{Pgr}^{\mathrm{Cre} /+}$ mammary glands exhibit poor proliferation at the lactational stage. This discrepancy in proliferation index can also be explained by the abnormal cell differentiation in this milieu since defects in alveologenesis consequentially cause proliferation failure during lactation (Jahchan et al. 2012). Although mammary gland defects may arise from decidual defects in Scrib ${ }^{f / f} \mathrm{Pgr}^{\mathrm{Cre} / \mathrm{t}}$ females (Yuan et al. 2019), this is remote possibility because mammary defects are already present on day 4 of pregnancy as opposed to uterine anomalies which occur after initiation of decidualization on day 5 of pregnancy onward (Yuan et al. 2019). This observation suggests that the abnormal differentiation of mammary glands occurs independently under this milieu. This assertion is also supported by the fact that PGR is poorly expressed in mammary glands at later stages of pregnancy (Ismail et al. 2002) and $P_{4}$ level drops upon parturition (Cha et al. 2012).

Previous reports using gene knockdown in cultured cells and MMTV-Cre-induced gene deletion in tissues have showed that abnormal cell polarity in mammary epithelia results in ductal formation defects (Zhan et al. 2008, Godde et al. 2014). The role of SCRIB in regulating cell polarity is well established in other contexts (Bonello \& Peifer 2019). In contrast, Scrib deletion by Pgr-Cre driver in our model does not appear to disturb apico-basal polarity. This indicates that SCRIB in the mammary gland has different functions depending on cell types. The importance of PGR for mammary gland development and functions during pregnancy and in puberty stages has previously been reported (Brisken \& Ataca 2015). Our observation suggests that SCRIB exerts its function in PGR-positive cells for cell differentiation in response to specific stimuli such as $\mathrm{P}_{4}, \mathrm{E}_{2}$, Prl during early pregnancy. Considering our results, high levels of $\mathrm{P}_{4}$ and PRL are critical factors that evoke SCRIB function in this context (Soares 2004, Cha et al. 2012). Since it has been reported that SCRIB binds to a variety of intracellular proteins to support their functions (Bonello \& Peifer 2019), it is possible that SCRIB interacts with molecules other than PRLR downstream in different cell types. Notably, Ltf-Cre-induced Scrib deletion in mammary epithelia does not result in apparent abnormal functions of the mammary gland, although reporter proteins were visible by this Cre driver and $\mathrm{SCr}$

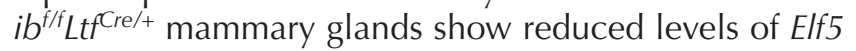
compared to floxed ones. One possible reason is that $L t f$ is primarily expressed in ductal epithelia, and a study using single cell RNA-seq shows poor expression of $L t f$ in PRLR or PGR-positive cells (Casey et al. 2018). It is also possible that ELF5 expression is independent of RANKL in the LTF-positive cells. Nonetheless, this cell type seems not to be critical for SCRIB functions.

In summary, our findings reveal that SCRIB facilitates differentiation of PGR-positive cells into mature alveolar cells, contributing to nourishment of offspring. Although our studies show that SCRIB plays a role in specific cell lineages, additional studies are needed to explore the cell-specific functions of SCRIB in the mammary gland and its impact on pregnancy and lactation.

\section{Supplementary materials}

This is linked to the online version of the paper at https://doi. org/10.1530/REP-20-0108.

\section{Declaration of interest}

The authors declare that there is no conflict of interest that could be perceived as prejudicing the impartiality of the research reported.

\section{Funding}

This work was supported in part by NIH grants (HD068524 and DA006668 to S K D) and a March of Dimes Centre grant (22FY17-889). S A was supported by the Astellas Foundation for Research on Metabolic Disorder Fellowship for Study Abroad and the Osamu Hayaishi Memorial Foundation Fellowship for Study Abroad. S A is currently supported by JSPS Overseas Research Fellowships.

\section{Author contribution statement}

$S A$, J Y and A D performed experiments, S A, X S and S K D designed experiments. S A, J Y and S K D analyzed data. S A, and $\mathrm{S} K \mathrm{~K}$ wrote the manuscript.

\section{Acknowledgements}

The authors thank Katie Gerhardt for her efficient editing of the manuscript. Pgr-Cre mice were originally obtained from Francesco DeMayo and John P Lydon (Baylor College of Medicine). Tobias B Huber (University Hospital Freiburg) originally provided the floxed Scribble mouse line.

\section{References}

Akhtar N \& Streuli CH 2006 Rac1 links integrin-mediated adhesion to the control of lactational differentiation in mammary epithelia. Journal of Cell Biology 173 781-793. (https://doi.org/10.1083/jcb.200601059)

Baker L, BeGora M, Au Yeung F, Feigin ME, Rosenberg AZ, Lowe SW, Kislinger T \& Muthuswamy SK 2016 Scribble is required for pregnancyinduced alveologenesis in the adult mammary gland. Journal of Cell Science 129 2307-2315. (https://doi.org/10.1242/jcs.185413)

Beleut M, Rajaram RD, Caikovski M, Ayyanan A, Germano D, Choi Y, Schneider P \& Brisken C 2010 Two distinct mechanisms underlie 
progesterone-induced proliferation in the mammary gland. PNAS $\mathbf{1 0 7}$ 2989-2994. (https://doi.org/10.1073/pnas.0915148107)

Bernard V, Young J \& Binart N 2019 Prolactin - a pleiotropic factor in health and disease. Nature Reviews: Endocrinology 15 356-365. (https:// doi.org/10.1038/s41574-019-0194-6)

Bonello TT \& Peifer M 2019 Scribble: a master scaffold in polarity, adhesion, synaptogenesis, and proliferation. Journal of Cell Biology $\mathbf{2 1 8}$ 742-756. (https://doi.org/10.1083/jcb.201810103)

Brisken C \& Ataca D 2015 Endocrine hormones and local signals during the development of the mouse mammary gland. Wiley Interdisciplinary Reviews: Developmental Biology 4 181-195. (https://doi.org/10.1002/ wdev.172)

Brisken C, Kaur S, Chavarria TE, Binart N, Sutherland RL, Weinberg RA, Kelly PA \& Ormandy CJ 1999 Prolactin controls mammary gland development via direct and indirect mechanisms. Developmental Biology 210 96-106. (https://doi.org/10.1006/dbio.1999.9271)

Brisken C, Ayyannan A, Nguyen C, Heineman A, Reinhardt F, Tan J, Dey SK, Dotto GP, Weinberg RA 2002 IGF-2 is a mediator of prolactininduced morphogenesis in the breast. Developmental Cell 3 877-887. (https://doi.org/10.1016/s1534-5807(02)00365-9)

Casey AE, Sinha A, Singhania R, Livingstone J, Waterhouse $P$, Tharmapalan P, Cruickshank J, Shehata M, Drysdale E, Fang H et al. 2018 Mammary molecular portraits reveal lineage-specific features and progenitor cell vulnerabilities. Journal of Cell Biology 217 2951-2974. (https://doi.org/10.1083/jcb.201804042)

Cha J, Sun X \& Dey SK 2012 Mechanisms of implantation: strategies for successful pregnancy. Nature Medicine 18 1754-1767. (https://doi. org/10.1038/nm.3012)

Cha J, Bartos A, Park C, Sun X, Li Y, Cha SW, Ajima R, Ho HY, Yamaguchi TP \& Dey SK 2014 Appropriate crypt formation in the uterus for embryo homing and implantation requires Wnt5a-ROR signaling. Cell Reports 8 382-392. (https://doi.org/10.1016/j.celrep.2014.06.027)

Daikoku T, Ogawa Y, Terakawa J, Ogawa A, DeFalco T \& Dey SK 2014 Lactoferrin-iCre: a new mouse line to study uterine epithelial gene function. Endocrinology 155 2718-2724. (https://doi.org/10.1210/ en.2014-1265)

Godde NJ, Sheridan JM, Smith LK, Pearson HB, Britt KL, Galea RC, Yates LL, Visvader JE \& Humbert PO 2014 Scribble modulates the MAPK/Fra1 pathway to disrupt luminal and ductal integrity and suppress tumour formation in the mammary gland. PLoS Genetics 10 e1004323. (https://doi.org/10.1371/journal.pgen.1004323)

Grimm SL, Seagroves TN, Kabotyanski EB, Hovey RC, Vonderhaar BK, Lydon JP, Miyoshi K, Hennighausen L, Ormandy CJ, Lee AV et al. 2002 Disruption of steroid and prolactin receptor patterning in the mammary gland correlates with a block in lobuloalveolar development. Molecular Endocrinology 16 2675-2691. (https://doi.org/10.1210/me.2002-0239)

Hartleben B, Widmeier E, Wanner N, Schmidts M, Kim ST, Schneider L, Mayer B, Kerjaschki D, Miner JH, Walz G et al. 2012 Role of the polarity protein Scribble for podocyte differentiation and maintenance. PLOS ONE 7 e36705. (https://doi.org/10.1371/journal.pone.0036705)

Hennighausen L \& Robinson GW 2005 Information networks in the mammary gland. Nature Reviews: Molecular Cell Biology 6 715-725. (https://doi.org/10.1038/nrm1714)

Hovey RC, Trott JF, Ginsburg E, Goldhar A, Sasaki MM, Fountain SJ, Sundararajan K \& Vonderhaar BK 2001 Transcriptional and spatiotemporal regulation of prolactin receptor mRNA and cooperativity with progesterone receptor function during ductal branch growth in the mammary gland. Developmental Dynamics 222 192-205. (https://doi. org/10.1002/dvdy.1179)

Ismail PM, Li J, DeMayo FJ, O'Malley BW \& Lydon JP 2002 A novel LacZ reporter mouse reveals complex regulation of the progesterone receptor promoter during mammary gland development. Molecular Endocrinology 16 2475-2489. (https://doi.org/10.1210/me.2002-0169)

Jahchan NS, Wang D, Bissell MJ \& Luo K 2012 SnoN regulates mammary gland alveologenesis and onset of lactation by promoting prolactin/ Stat5 signaling. Development 139 3147-3156. (https://doi.org/10.1242/ dev.079616)

Lee HJ, Gallego-Ortega D, Ledger A, Schramek D, Joshi P, Szwarc MM, Cho C, Lydon JP, Khokha R, Penninger JM et al. 2013 Progesterone drives mammary secretory differentiation via RankL-mediated induction of Elf5 in luminal progenitor cells. Development 140 1397-1401. (https://doi. org/10.1242/dev.088948)
Lydon JP, DeMayo FJ, Funk CR, Mani SK, Hughes AR, Montgomery CA, Shyamala G, Conneely OM \& O'Malley BW 1995 Mice lacking progesterone receptor exhibit pleiotropic reproductive abnormalities. Genes and Development 9 2266-2278. (https://doi.org/10.1101/ gad.9.18.2266)

Mallepell S, Krust A, Chambon P \& Brisken C 2006 Paracrine signaling through the epithelial estrogen receptor alpha is required for proliferation and morphogenesis in the mammary gland. PNAS 103 2196-2201. (https://doi.org/10.1073/pnas.0510974103)

Miyoshi K, Shillingford JM, Smith GH, Grimm SL, Wagner KU, Oka T, Rosen JM, Robinson GW \& Hennighausen L 2001 Signal transducer and activator of transcription (Stat) 5 controls the proliferation and differentiation of mammary alveolar epithelium. Journal of Cell Biology 155 531-542. (https://doi.org/10.1083/jcb.200107065)

Neville MC \& Zhang P 2000 Lactoferrin secretion into milk: comparison between ruminant, murine, and human milk. Journal of Animal Science 78 26-35. (https://doi.org/10.2527/2000.78suppl_326x)

Nola S, Sebbagh M, Marchetto S, Osmani N, Nourry C, Audebert S, Navarro C, Rachel R, Montcouquiol M, Sans N et al. 2008 Scrib regulates PAK activity during the cell migration process. Human Molecular Genetics 17 3552-3565. (https://doi.org/10.1093/hmg/ddn248)

Oakes SR, Naylor MJ, Asselin-Labat ML, Blazek KD, Gardiner-Garden M, Hilton HN, Kazlauskas M, Pritchard MA, Chodosh LA, Pfeffer PL et al. 2008 The Ets transcription factor Elf5 specifies mammary alveolar cell fate. Genes and Development 22 581-586. (https://doi.org/10.1101/ gad.1614608)

Obr AE, Grimm SL, Bishop KA, Pike JW, Lydon JP \& Edwards DP 2013 Progesterone receptor and Stat5 signaling cross talk through RANKL in mammary epithelial cells. Molecular Endocrinology 27 1808-1824. (https://doi.org/10.1210/me.2013-1077)

Paine IS \& Lewis MT 2017 The terminal end bud: the little engine that could. Journal of Mammary Gland Biology and Neoplasia 22 93-108. (https://doi.org/10.1007/s10911-017-9372-0)

Palmer CA, Neville MC, Anderson SM \& McManaman JL 2006 Analysis of lactation defects in transgenic mice. Journal of Mammary Gland Biology and Neoplasia 11 269-282. (https://doi.org/10.1007/s10911-006-90233)

Plante I, Stewart MK \& Laird DW 2011 Evaluation of mammary gland development and function in mouse models. Journal of Visualized Experiments. (https://doi.org/10.3791/2828)

Psychoyos A 1973 Endocrine Control of Egg Implantation. In Handbook of Physiology Section 7 vol. II part 2 pp. 187-215. Ed. RO Greep; Washington, DC: American Physiology Society.

Sackmann-Sala L, Guidotti JE \& Goffin V 2015 Minireview: prolactin regulation of adult stem cells. Molecular Endocrinology 29 667-681. (https://doi.org/10.1210/me.2015-1022)

Saji S, Jensen EV, Nilsson S, Rylander T, Warner M \& Gustafsson JA 2000 Estrogen receptors alpha and beta in the rodent mammary gland. PNAS 97 337-342. (https://doi.org/10.1073/pnas.97.1.337)

Scheele CL, Hannezo E, Muraro MJ, Zomer A, Langedijk NS, van Oudenaarden A, Simons BD \& van Rheenen J 2017 Identity and dynamics of mammary stem cells during branching morphogenesis. Nature 542 313-317. (https://doi.org/10.1038/nature21046)

Shillingford JM, Miyoshi K, Robinson GW, Grimm SL, Rosen JM, Neubauer H, Pfeffer K \& Hennighausen L 2002 Jak2 is an essential tyrosine kinase involved in pregnancy-mediated development of mammary secretory epithelium. Molecular Endocrinology 16 563-570. (https://doi.org/10.1210/mend.16.3.0805)

Soares MJ 2004 The prolactin and growth hormone families: pregnancyspecific hormones/cytokines at the maternal-fetal interface. Reproductive Biology and Endocrinology 2 51. (https://doi.org/10.1186/1477-7827-251)

Soyal SM, Mukherjee A, Lee KY, Li J, Li H, DeMayo FJ \& Lydon JP 2005 Cremediated recombination in cell lineages that express the progesterone receptor. Genesis 41 58-66. (https://doi.org/10.1002/gene.20098)

Sternlicht MD 2006 Key stages in mammary gland development: the cues that regulate ductal branching morphogenesis. Breast Cancer Research 8 201. (https://doi.org/10.1186/bcr1368)

Wagner KU, Wall RJ, St-Onge L, Gruss P, Wynshaw-Boris A, Garrett L, Li M, Furth PA \& Hennighausen L 1997 Cre-mediated gene deletion in the mammary gland. Nucleic Acids Research 25 4323-4330. (https://doi. org/10.1093/nar/25.21.4323) 
Wang RA, Vadlamudi RK, Bagheri-Yarmand R, Beuvink I, Hynes NE \& Kumar R 2003 Essential functions of p21-activated kinase 1 in morphogenesis and differentiation of mammary glands. Journal of Cell Biology 161 583-592. (https://doi.org/10.1083/jcb.200212066)

Yuan J, Deng W, Cha J, Sun X, Borg JP \& Dey SK 2018 Tridimensional visualization reveals direct communication between the embryo and glands critical for implantation. Nature Communications 9 603. (https:// doi.org/10.1038/s41467-018-03092-4)

Yuan J, Aikawa S, Deng W, Bartos A, Walz G, Grahammer F, Huber TB, Sun X \& Dey SK 2019 Primary decidual zone formation requires Scribble for pregnancy success in mice. Nature Communications 105425. (https://doi.org/10.1038/s41467-019-13489-4)
Zhan L, Rosenberg A, Bergami KC, Yu M, Xuan Z, Jaffe AB, Allred C \& Muthuswamy SK 2008 Deregulation of scribble promotes mammary tumorigenesis and reveals a role for cell polarity in carcinoma. Cell 135 865-878. (https://doi.org/10.1016/j.cell.2008.09.045)

Received 24 February 2020

First decision 9 March 2020

Revised manuscript received 13 March 2020

Accepted 26 March 2020 